\title{
The Water Framework Directive: A New Directive for a Changing Social, Political and Economic European Framework
}

\author{
MARIA KAIKA
}

\begin{abstract}
This article examines the intricate process of developing the European Union's Water Framework Directive. It sees the Directive as a response to recent economic, political and social changes related to water management, including the shift from government to governance, the liberalization of water markets and the emergence of a new set of institutions, actors, etc. and their respective relations (i.e. social capital). The article focuses on the key points of disagreement between the Council of Ministers and the European Parliament that threatened to prevent the Directive from being materialized and interprets this controversy as the culmination of conflicting interests between different actors at the local, national and European levels. Finally, it asserts the increasingly important role of the nation state in the decision-making and implementation of the Directive and sets this against recent arguments about the death of the State.
\end{abstract}

\section{Introduction}

The European Water Framework Directive (WFD) is a legally binding policy that provides a common framework for water management and protection in Europe and that promises to transform the European water sector. The document was voted in by the European Union's Plenary Session in September 2000 and came into force in December 2000. The decision for establishing a new framework for water management in Europe happened within a changing social and political framework. The increasing internationalization and complexity of water resource management (ICWS, 1996), the increasing number of actors and institutions involved in this process, the newly vested economic interests in water supply, and the increasing concern and sensitivity towards environmental protection, are amongst the factors that made the political ecology of water at the local, national, European and international levels more complex and important (Reisner, 1990; Hundley, 1992; Postel, 1992; Faure \& Rubin, 1993; Gleick, 1993).

This article examines the often conflicting interests between the new institutions, actors and levels of governance that have replaced the traditional State-led approach to decisionmaking, and studies the debate that formulated the binding objectives of the WFD as the culmination of the social, political and economic interests at the local, regional, national and European levels. After providing a brief history of European water policy, the article presents the broader social, political and economic framework within which the decision to change 
European Union water policy was made. It examines the shift from government to governance and the accompanying changing role of the State and the emergence of the new set of actors. In what follows, the article examines the conflicts and alliances between these actors as they were culminated in the different positions between the European Council (EC) and the European Parliament (EP). The article concludes with the remark that despite the exile of the State and the shift towards practices of governance, the implementation phase of the Directive demands that nation states play a central role and set the requirements for establishing new networks of actors, old and new (social capital).

\section{European Water Policy: Past and Present}

The development of the European legislation for water resources can be grouped into three 'waves' (see Table 1). The first wave goes back to 1975 (Kallis \& Nijkamp, 2000) when the surface water directive and the drinking water directive were enacted. Those first directives focused predominantly on water quality standards and on the protection of surface waters that are allocated for drinking (Da-Cunha, 1989). The second wave of European water legislation came in 1991 and focused, for the first time, not only on setting acceptable water quality standards, but also on controlling emission levels as a means of achieving the desired standards. The new legislation included the Urban Wastewater Management Directive, the new Drinking Water Quality Directive, the Nitrates Directive, and the Directive for Integrated Pollution and Prevention Control.

The WFD comprises what is now known as the 'third wave' of European water legislation and, in many ways, it combines the two preceding approaches and provides a common framework for European Union water policy. Firstly, it introduces a new approach to water management based on river basins (an integrated approach), linking for the first time physical planning with water resource planning. Secondly, it stipulates that water quality cannot be seen outside emission controls and groundwater protection (a combined approach) (ECT/IW, 1998). Once it becomes fully operational, the WFD will replace all the water directives that are currently operational (see Table 1; European Commission, 2000a, 2000b).

\section{Responding to Social, Political and Economic Ghanges: From Government to Governance and the Accumulation of Social Capital}

Development of the WFD began in 1995 when the Environment Commission of the European Union (EC), the Environmental Commission of the European Parliament (EP) and the Council of Environment Ministers of the European Union (CM) agreed to embark upon a more global approach to water policy (ECEWTF, 1997; WWF, 2000). The Commission (EC) conducted a first draft communication for a new water legislation (European Commission, 1996, $\operatorname{COM}(96) 315)$, which stipulated the aims of this legislation. The decision, however, to reform radically European Union water legislation did not come unexpectedly; it was a response to a rapidly changing political, economic and social framework and to changes in what constitutes 'social capital' at the local, regional, national and European levels. Social capital is understood here as the formal and informal norms, bonds and relationships and 'culture' of social interaction between social actors and the degree of 'cohesion' within a society (Putnam, 1995; Coleman, 1988; Pretty \& Ward, 2001) that affect the ability of a society to assimilate change or implement policies and reach goals (Woolcock, 1998). Within the last two decades, we can identify three major parameters of change in social capital formation at different levels of governance, related to the way water is perceived, used and managed.

The first parameter of change is the multiplication of the actors involved in water management and the reconfiguration of their respective roles (Gottlieb, 1988; Goubert, 1989; 
Table 1. A chronology of the European legislation on water

\author{
First Wave of Legislation \\ Focus on water quality objectives (WQO) \\ 1975 The surface water directive \\ 1980 The drinking water directive \\ Second Wave of Legislation \\ Focus on emission limit value approach (ELV) \\ 1991 Urban Waste Water Management Directive \\ $1991 \quad$ Nitrates Directive \\ New Drinking Water Directive \\ 1996 \\ Directive for Integrated Pollution and Prevention Control
}

Third Wave of Legislation (The Water Framework Directive)

Integrated approach

February 1996

February 1997

November 1997

January 1998

February 1998

June 1998

Summer 1998

Autumn/Winter

January 1999

Commission's Communication on European Water Policy

Commission's Proposal for a Water Framework Directive (COM(97)49)

Commission's amended proposal following consultation (COM (97) 614)

Involvement of environmental NGOs in amending Annex $\mathrm{V}$ on the proposed WFD

Commission's further amendment of proposal following consultation (COM (98) 76)

Council of Ministers adopt provisional common position on the WFD

Environment Committee of the European Parliament amends proposed WFD and reveals substantial differences between Council of Ministers and European Parliament over the text

European Parliament deliberately postpones giving the WFD a first reading in order to achieve co-decision status

Informal conciliation talks under the auspices of the German Presidency of the European Union between European Parliament, European Commission and Council of Ministers

February $1999 \quad$ European Parliament gives draft WFD its first reading - votes to accept 120 of the amendments made by the Environment Committee to the Commissions text.

Summer 1999 Legislative Process delayed by elections for European Parliament.

European Commission accepts many of the amendments made by the European Parliament, but the Council of Ministers does not and reverts to the political agreement of June 1998.

Autumn/Winter 1999 Environment Committee of the European Parliament re-tables their proposed amendments (PE 231.246) knowing the WFD will have co-decision status

February 2000 European Parliament give draft WFD its second reading, accepting the bulk of the amendments proposed by the Environment Committee, and challenges the common position adopted by Council of Ministers

May 2000 First round of formal conciliation talks between European Union institutions unsuccessful

June 2000

September 2000

Second round of formal conciliation talks produce a compromise WFD

December 2000 The text drawn up in the conciliation talks formally approved the plenary session of the Parliament and by the Council of Minister

WFD (Directive 2000/60/EC) published in the official gazette $\left(22^{\text {nd }}\right.$ December 2000 L 327/1), member states have 3 years from this date to transpose it into national legislation

Source: compiled by the author and annotated by Dr. Ben Page.

Anon, 1994) with immediate social and political effects (Swyngedouw, 1997). To start with, the growth of urban areas, the expansion of their ecological footprint, and the need to harness water from further away (often crossing national boundaries) has generated the need for regional and international agreements for water sharing and management and for developing new institutions to manage such agreements. In addition to that, the liberalization and 
subsequent internationalization of water markets has introduced the private sector as a new and powerful player in the field of water resource management and distribution and has created the need for further institutional regulation (Neto, 1998), thus generating an increasingly complex set of actors and institutions, such as governmental organizations and industrial organizations, which are necessary to regulate and control the water market (Frederiksen, 1930(1992); Saleth et al., 2000). Water supply projects are no longer just one part of a State-led development of the collective means of consumption; they are also opportunities for market development, dealt with according to the 'laws' of the market economy and regulated through new institutional structures.

The second parameter of change is the multiplication of power centres and scales at which decision-making is exercised in the water sector. This is an immediate effect of the multiplication of actors and of the changes in their respective roles (Ernst, 1994; Swyngedouw et al., 2000). The complex system of institutions and actors, needed to deal with water management at the local, national, European and international scale, relocated water politics, economics and management from the sphere of the local into the sphere of the global (Ogden, 1995; Swyngedouw, 2000). This, in fact, reflects and compliments a more general international reconfiguration and rescaling of power centres, the emergence of the European Union itself being one of them. This rescaling of decision-making is also part of the shift from a centralized, Keynesian, State-led and State-controlled management (government) to a postKeynesian management based on fragmented decision-making clusters (governance) (Jessop, 1997). These clusters structure formal and informal relations, sometimes bypassing the nation state in their decision-making. This does not mean that the relations amongst the different levels and clusters of governance are free of power formations. Indeed, the power configuration amongst these groups lies at the heart of their debates and is far from being static (Harvey, 1989).

Finally, another important parameter of change in water management and politics is the increasing concern for the environment. Environmental protection, hardly a consideration in the first stages of industrial urbanization, now features centrally in debates about water supply and management at all levels of governance (European Commission, 1992; EEA, 1995, 1998, 1999a, 1999b, 1999c). For example, today, new dam projects in European countries cannot be approved unless accompanied by an environmental impact assessment. A large amount of 'social capital' (Pretty \& Ward, 2001) has accumulated in Europe and is efficiently invested in environmental protection, comprising non-governmental organizations (NGOs), quasi-non governmental organizations (quaNGOs), institutions, regulatory bodies, as well as civil groups and networks of people whose loyalties lie predominantly, if not solely, with the protection of the environment. The discourse and agendas of these environmental groups and organizations are in constant dialogue (opposition or accordance) with local, national and international economic and political agendas.

\section{Burying the State and Reforming the Gitizen: From Political Action to Participation}

The emergence of the aforementioned new set of scales, actors and relations has had profound effects on decision-making and on the ways in which political concord or opposition is voiced. In fact, a whole new way of 'doing politics' has emerged, whereby political action in its traditional form (i.e. protests, strikes, barricades, etc.) is giving way to practices of participation (Kearns, 1995). The main rationale behind this is that decision-making centres (e.g. the Commission) foresee potential opposition or conflict and put forward practices of incorporating the opposing groups of actors into the decision-making process, thus opening a dialogue which can potentially diffuse conflict at its nascent stage. Within the European Union in 
particular, there is a very strong stance for conflict management through participation and later on in this article we shall see how this process worked in the development of the WFD.

Directly related to such significant political changes are changes at the ideological/ discursive level. At this level, political actors have been substituted by stakeholders (Burkitt \& Ashton, 1996), the citizen by the consumer, while the discursive representation of water attempts to strike the rather unattainable balance between a widely accepted social role as a public good and a heritage and its newly inflated economic role as a market commodity. Indeed, within the final text of the WFD, this contradiction in water's perceived social role (public good versus commodity) is striking: the text starts by defining water as Europe's heritage and ends by asserting the importance of the economic value of water and the need to focus on water pricing as the best way to manage Europe's water resources. In what follows, we shall see in more detail how the above changes in actors, institutions and social power relations filtered into the debate for the making of the WFD.

\section{Choosing Interlocutors: Potential versus Ability to Participate}

The tendency to substitute political action with participation is particularly strong in the decision-making process at the European level. This is partly to compensate for the difficulty of performing direct political action at the European level. The final text of the WFD itself stipulates that there must be 'active public involvement' in river basin management planning. This, however, neither guarantees a fully inclusive participatory process, nor excludes the implication of relations of social power in the ability of each actor (or stakeholder) to participate. Although the European Union asserts its commitment to involve the public in the decision-making and implementation phases of its directives, practices of participation are not institutionally defined and neither are the roles of different political actors (e.g. professional organizations, NGOs, etc.). Thus, the question of who participates, where, and how, and what are the respective roles and interests of the participating actors becomes a key to understanding the mechanisms and politics behind the decision-making process.

In the case of the WFD, the obvious participating actors were the EC, the EP and the European CM. However, immediately after the first communication on the WFD, the EC launched an open call for participation at the drafting of the Directive, which meant that, potentially, everybody could participate. Nevertheless, in parallel to launching the open call, the Commission also invited specific groups and organizations to participate, which spanned: water suppliers; the chemical and fertilizer industry; the agricultural sector and farmers unions; NGOs; regulators; and the water industry in countries with privatized water services. So, outside the open call for participation, as one of its members put it during an interview, the Commission 'chose its interlocutors' (Personal Communication, September 2000). Having said that, the selected interlocutors represented a wide range of mainly conflicting interests; thus the Commission can by no means be accused of bias towards one particular political or social interest. It should also be noted that the Commission remained fully open and carefully considered suggestions and input coming not only from invited actors but also from all stakeholders who participated out of their own initiative, such as: local authorities, landowners associations, statutory agencies or consumers' associations.

For those groups who were not directly targeted by the Commission, the question of participation remained largely a question of dissemination of information. The European Union is committed to disseminating information on environmental issues, and this is guaranteed by the Directive 90/313/EEG on Access to Environmental Information (European Commission, 1998, p. 25). However, inevitably so, dissemination of information was not homogeneous at all levels of governance or for different member states, given that the quality and quantity of disseminating information varied from member state to member state, 
depending on how much importance each member state put on this process. Still, associations, organizations and activist groups were free to access information directly at the European Union level, but they could do so only if they had the resources and the 'know how'. Thus, groups and organizations who held a Brussels bureau, such as: the Eureau (European Union of National Associations of Water Suppliers and Waste Water Services), the EEB (European Environmental Bureau), WWF (World Wildlife Fund), Greenpeace, the ECPA (European Crop Protection Association), the EFMA (European Fertilizers Manufacturers Association) had a distinct advantage in accessing information at the European Union level and did much better in keeping informed as well as in raising their voices pro or against the main objectives of the WFD. More importantly, these groups also had the opportunity to develop a strong lobbying position vis-à-vis both the EP and the EC, thus developing a double lobbying power: one practised at the national level by lobbying their national Environment Ministers, and transferred at the European Union level via the CMs; and one practised at the Europen Union level, by lobbying directly the Commission and the EP. Thus, although it could be argued that according to the principles of democratic representation local groups can and should adequately be represented at the European Union level through the CMs, in practice, groups and organizations who could hold a Brussels bureau had a distinct advantage over others, particularly given the controversial character of the Directive, which meant that the Ministers of the European Council had to represent very conflicting local and national interests at the European level.

Appreciably, the geographical location of those groups' headquarters at Brussels is the outcome rather than the cause of their relatively more powerful position with respect to smaller groups and organizations. Indeed, Brussels based groups are mainly ones who can afford the resources to have a Brussels bureau and a dedicated person to follow the intricacies of the decision-making process at the European Union level. Thus, within the new 'governance' regime, location becomes a more rather than less significant factor for the successful promotion of political agendas since access to lobbying gains even more political importance (Kearns, 1995). This creates the potential for a dissymmetry in participating and developing lobbying power between different groups, and although in theory all stakeholders have equal access to participation, in practice, well-funded and experienced groups hold a 'structural' advantage in the participatory mechanisms at the European level.

Another question that needs to be addressed is what exactly is meant by participation. Since participation is a very complex concept that could mean anything from sharing decision-making to being informed of what has been decided (Pretty \& Hine, 1999), we need to clarify that participation in the making of the WFD meant consultation, i.e. participating groups could voice their opinion and consult the Commission (although the Commission was not obliged to take on board suggestions and views) but could not share in the decision-making (Harrison et al., 2001). Actors could communicate their ideas in writing or/and organize networks, discussion forums and conferences, some of which were co-funded by the Commission. In the next section, we shall identify the most important positions and points of conflict between the various participating actors, which were put forward from the very beginning and were contested until the very end.

\section{Multiple Levels of Discord and Conflicting Agendas}

Although it is not easy to find common denominators for the wide variety of groups and interests represented, Figure 1 is an attempt to classify the clusters of interests within the main groups of actors, with respect to three main controversial points of the directive: full cost pricing, hazardous substances and the implementation timeline.

Environmental NGOs were heavily involved in the process of drafting the WFD. How- 


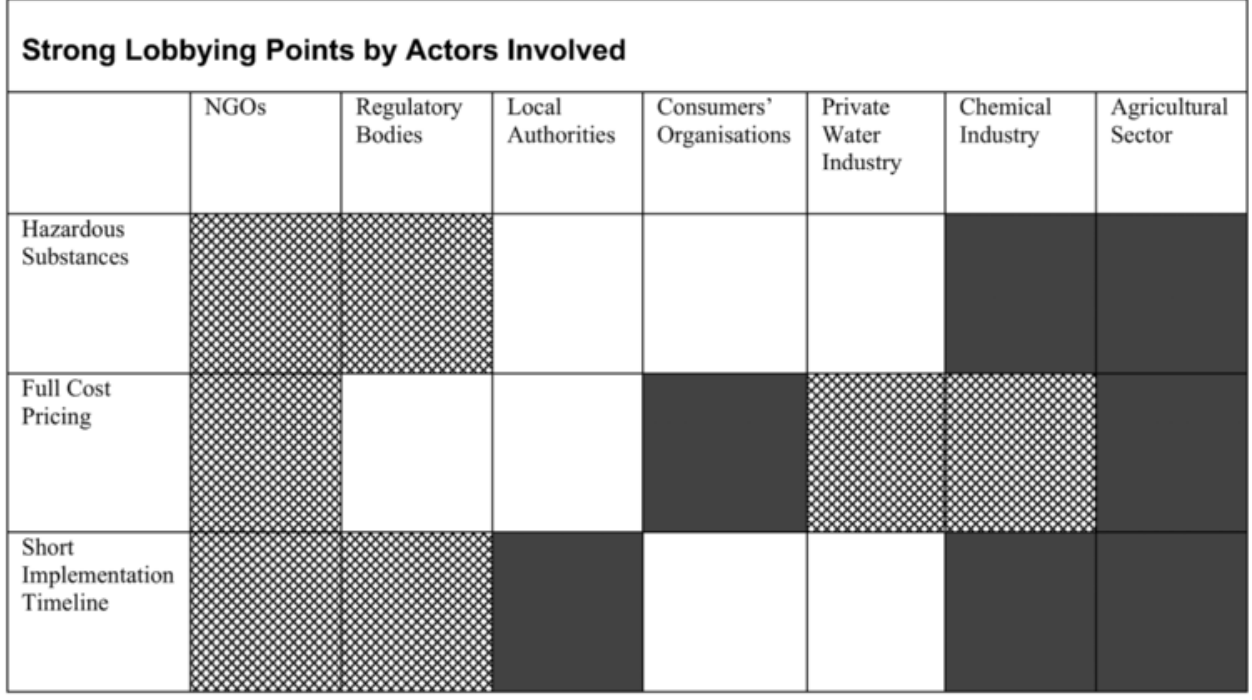

Strong Agreement; $\mathbf{\square}$ Strong Disagreement

Figure 1. Classification of clusters of interests amongst main actors with respect to the three main controversial points of the directive. Source: compiled by the author.

ever, different NGOs did not always have the same agendas or priorities: the RSPB (Royal Society for the Protection of Birds), for example, focused mainly on the directive's impact on wetlands, while the EEB and the WWF pushed forward the agendas of the cessation of emission of hazardous substances and groundwater protection. Still, environmental NGOs did have common points of interest for which they lobbied rather successfully, such as: the incorporation of the Esbjerg declaration (cessation of discharges of hazardous substances) (Meyer, 1988); the incorporation of the OSPAR treaty (zero emission of priority hazardous substances (PHS)); stricter implementation timelines; and a focus (controversially, at times) on full cost pricing as a means of environmental protection.

QuaNGOs and regulators under privatized water markets welcomed and strongly supported the WFD as a means of facilitating, complementing and enforcing regulation and environmental protection. Martin Griffiths, from the Environment Agency, noted that the WFD is: 'intellectually, exactly what we want'. River basin management in particular is considered by regulators to be a unique opportunity to develop further coordination of the actions of public authorities (Henton, 2000). There is, however, concern amongst regulatory bodies about the integration of the new regulatory regime imposed by the WFD with existing regulatory regimes and institutions. Recently, the Environment Agency (UK) noted that:

... because [the WFD] ... effectively overhauls the existing water management regime, its implementation will significantly affect the way in which the Agency carries out its business.... implementation will have consequences for the ... planning and environmental monitoring functions of the Agency. (Wood, 2001)

Local authorities had very mixed feelings about the directive. Although many local authorities responded to the initial call for consultation in the form of consultation papers, they did not lobby directly during the conciliation phase. This was mainly due to the fact that local authorities felt confident that their interests were adequately represented at the European Union level by their respective ministers. In fact, interviews conducted in November 2000 
showed that many local authorities around Europe were not even aware of the WFD, or had heard about it but thought it had nothing to do with them. However, local authorities increasingly realize that the WFD will affect them considerably through its requirements for river basin management, and for the establishment of River Basin Authorities. In effect, the WFD recasts the relationship between physical, political and administrative boundaries, and for this reason represents a thorny issue for local authorities in many European countries, which see statutory planning (including issuing abstraction licenses) as one of their major mechanisms for exercising power. Thus, local authorities have deep concerns regarding the loss of power to the new administrative structure dictated by the WFD and one representative went as far as to declare the "death of statutory planning as we know it" (Gilbert, 2000). Consequently, many local authorities are adopting a more informed and active approach during the implementation phase, in which we are at the moment (European Commission, 2001).

The public water supply sector was mainly represented through local and national governments, and largely left the decision-making to the respective ministers. However, the privatized water industry pursued firmly its interests both at the national level through lobbying environment ministers and at the European level, where their European association, Eureau exercised its lobbying power towards the EP and the EC. Predictably enough, the industry supported full cost pricing, an issue on which they found a strong ally with environmental NGOs. While full cost pricing would give the industry the green light to increase the price of water in the name of 'environmental protection', the prospect of better water quality through the implementation of the Directive would reduce treatment costs, thus allowing the water industry to reap a double benefit (increased prices, reduced production cost). According to the European Union's 'polluter-pays principle' (Article 174(2) of the EC Treaty, see also European Commission, 2000a) the cost of environmental protection and 'clean up' should burden the industries and agricultural producers that cause this pollution, and not the producer of water.

However, it is another European Union principle incorporated in the WFD, the 'user pays principle' that remains thorny for the water industry. According to this principle, it is the water supplier and potentially the consumer who should pay the cost of the environmental damage caused by the use of water, via, for example, the construction of dams or abstractions. Given that obtaining new abstraction licences is more economical for the industry than, for example, increasing leakage control, the industry is always keen on expanding its abstraction base. However, the Directive's potentially strict abstraction standards can make such practices more difficult in the future. Thus, the water industry is trying to find ways around a stricter licensing regime. For example, recently, in its response to the UK Government consultation on the WFD, the UK water industry marshalled arguments about climate change rather than over-abstraction being a possible cause for saline intrusion, thereby asking for a transfer of responsibility (and cost) for overabstraction to the climate rather than to the industry!

Saline intrusion is not only a symptom of 'overabstraction' but can also be due to sea level rise resulting from climate change. It is our view that the term 'overabstraction' should be used in the context of abstraction above the licensed allocation. ... The use of the term 'overabstraction' may pre-judge the outcome of studies to evaluate the best option to deal with any issue. (Water UK, 2001)

The Chemical Industry's main concern lies with the combined approach of the Directive, namely the combination of environmental quality standards with emission limit values. The industry will be affected heavily by the Directive's requirement for phasing out PHS within 20 years. Thus, the chemical industry's association was actively involved in the final process of identifying PHS, pushing forward its own agenda for moderating the requirement for zero emission of such substances, and contrasting the agendas of NGOs' who argued for the 
incorporation of as many substances in the list as possible. Commenting on the Directive's final text, the representative of the chemical industry's association contended that "the directive goes much further than expected" (Hackitt, 2000). The same representative called for a "realistic [?] definition of zero [!] emissions of priority hazardous substances". However, a point on which the chemical industry finds itself in accord with both the water industry and NGOs is full cost pricing, but it argues that environmental costs, including the cost for cessation of discharges of PHS (which the industry estimates for the UK only between 200 and 1000 million Euros) should be met by the European citizen and not by the chemical industry itself.

The agricultural sector is also potentially heavily affected by changes in water management (Garrod \& Willis, 1994). It would be wrong to treat the agricultural sector as one uniform agent, since it comprises very powerful and financially robust lobbies as well as thousands of small units who struggle financially (the latter category counts 70,000 units in the UK alone). Given, however, that the agricultural industry is the main diffusion polluter, there have been several issues unifying the sectors' response to the WFD, the main being the concern about the directive's groundwater protection requirements and about a potential increase in the price of water. The industry recognizes that diffusion pollution represents both a loss to the farmers and a waste of resources, but argues that this problem should be tackled through primary resource management (i.e. water and soil) and through educating farmers further about pesticide use (Tompkins, 2000). As far as their use of water resources is concerned, they consider themselves to be 'consumers', at the end of the line of water production. Thus, they argue against full cost pricing or any other financial instrument for environmental protection since such choices would increase the cost of water and subsequently the cost of agricultural production, leading, in turn, to an inevitable increase in the price of agricultural products. For this reason, arguments about protecting their competitiveness in international markets as well as about food security are put forward by the agricultural sector. However, they also pre-empt a different outcome by arguing that should full cost pricing and environmental cost recovery be implemented, the financial cost should burden the State or the consumer of agricultural products (instead of the producer of agricultural products).

Apart from the above actors and their respective interests, member states within the European Union had varying national economic, political and social interests that led to very different national positions with respect to the WFD. It should be noted, however, that what were expressed at the European level as 'national agendas' (i.e. what the Ministers of member states promoted at the European Council) were compromises between contrasting interests of lobbies at the national level: between the water and the agricultural industry over water pricing; between the chemical industry and the water industry over water quality; and between pressures at the local level for environmental protection versus pressures for further development of the agricultural sector. Although the WFD has been accused of being a 'Northern European Directive' because of its focus on water quality rather than water quantity issues (EEA \& ECT/IW, 1996), during the debates between the EP and the CM the traditional north/south divide was barely evident. For example, Ireland, which had introduced a new charging system with zero domestic charges only 1 month before the proposal was adopted, allied with the European south against full cost pricing. Portugal, however, allied with the European north on the issue of strict river basin management, partly because the imminent Spanish national hydrological plan will affect Portuguese water flows. Such atypical alliances did not merely form at the nation state level: in what follows, we shall see how the conflicts and alliances between different member states and different lobbying actors and organizations culminated in the positions that the European Council and the EP took in response to the Commission's proposal. 


\section{European Parliament versus European Council: Internal Gonflict, or the Gulmination of Incompatible Agendas?}

May 1996 marked the end of the official consultation process and, in February 1997, the commission drafted the first proposal for a European Framework Directive on Water (European Commission, 1997, COM(97)49), the main targets of which were:

- surface and groundwater protection;

- good status' for all waters by a certain deadline;

- an integrated approach to water management (based on river basins);

- a combined approach to water management (emission limit values and diffusion pollution along with quality standards);

- getting prices 'right';

- getting the citizen involved (Bloech, 1999; see also Boymanns, 1997).

According to the standard European Union institutional procedure, the CM and the EP had to conduct separate readings of the proposal and suggest amendments that would then go back to the Commission, who would accept or reject them. Subsequently, after the Commission's assessment of the amendments, the text had to go back to the EP and the EC for voting. Although it may sound like a bureaucratic exercise, this process involved important and complex negotiations. Soon after the Commission offered the proposal to the EP and the CM for reading and amending, it became clear that the two decision-making bodies disagreed on a number of key issues. The EP, being more detached from, and therefore more resilient to, national networks of influence, supported far stricter requirements for environmental protection and implementation timelines. The CM, however, trying to juggle the often conflicting interests between national industries, public organizations, implementation costs, etc., adopted a more lenient approach (see Table 2). The three major points of conflict that remained controversial throughout the drafting process were:

- the legally binding character of the directive's objectives (implementation timeline);

- the provision for cessation of release of hazardous substances (directly linked to the introduction of groundwater protection);

- water pricing (full cost pricing and environmental cost recovery).

The result was that the Parliament's position was almost antithetical to that of the Council's on all three of the above issues. At this point (1998), however, it was the Council who had legislative power according to the Maastricht Treaty, while the Parliament could only amend the Council's proposed legislation after the Council had drafted it. The EP foresaw that if the CM were to go ahead with voting its amended proposal, the WFD would present a much weaker environmental legislation than the set of directives it would repeal. In order to prevent this from happening, the EP made a very important political manoeuvre and decided not to consider the WFD before the Amsterdam Treaty (AT) came into force on 1 May 1999.

The AT (signed on 17 June 1997) radically altered the status of the decision-making procedure in the European Union from a cooperative process between the Council and the Parliament to a co-decision process between the Council and the Parliament. By shifting the power balance between the EP and the $\mathrm{CM}$, the AT gave equal negotiating powers to the Parliament, thus making the importance of the disparity of views on the WFD between the EP and the CM even greater and thereby affecting profoundly the final text of the WFD and possibly that of future environmental legislation (Bär \& Kraemer, 1998).

The disagreement between the EP and the CM may appear to be an 'internal' conflict between the two main decision-making bodies of the European Union but was, in fact, the culmination of conflicting social, economic and political interests involving a number of actors 
Table 2. Comparative table of the positions of the European Parliament and the European Council of Minister during the two readings of the WFD

\begin{tabular}{|c|c|c|c|}
\hline \multicolumn{2}{|c|}{ First Reading } & \multicolumn{2}{|c|}{ Second Reading } \\
\hline $\begin{array}{l}\text { Council } \\
\text { (June 1998) }\end{array}$ & $\begin{array}{c}\text { Parliament } \\
\text { (February 1999) }\end{array}$ & Council (March 1999) & $\begin{array}{c}\text { Parliament } \\
\text { (February 1999) }\end{array}$ \\
\hline $\begin{array}{l}\text { Increase } \\
\text { implementation } \\
\text { period ( } 16 \text { years) }\end{array}$ & $\begin{array}{l}\text { Keep implementation } \\
\text { period/oblige member } \\
\text { states to report on progress }\end{array}$ & $\begin{array}{l}\text { Increase implementation } \\
\text { period ( } 34 \text { years)/member } \\
\text { states should 'make an effort' } \\
\text { to implement WFD }\end{array}$ & $\begin{array}{l}\text { Reduce } \\
\text { implementation } \\
\text { period ( } 10 \text { years) }\end{array}$ \\
\hline $\begin{array}{l}\text { Reject full cost } \\
\text { recovery }\end{array}$ & $\begin{array}{l}\text { Water is Europe's } \\
\text { heritage, not a } \\
\text { commercial product }\end{array}$ & Delete full cost pricing & $\begin{array}{l}\text { Water is Europe's } \\
\text { heritage, not a } \\
\text { commercial product }\end{array}$ \\
\hline \multirow[t]{2}{*}{$\begin{array}{l}\text { Add list of } \\
\text { derogations }\end{array}$} & No derogations & Increase list of derogations & $\begin{array}{l}\text { Increase legally } \\
\text { binding requirements }\end{array}$ \\
\hline & $\begin{array}{l}\text { Incorporate Esbjerg } \\
\text { declaration/Identify } \\
\text { priority hazardous } \\
\text { substances for } \\
\text { immediate cessation/ } \\
\text { Continuous reduction } \\
\text { of all other hazardous } \\
\text { substances }\end{array}$ & $\begin{array}{l}\text { Abandon zero emission } \\
\text { approach for hazardous } \\
\text { substances }\end{array}$ & $\begin{array}{l}\text { Fully incorporate } \\
\text { OSPAR }\end{array}$ \\
\hline
\end{tabular}

Source: compiled by the author.

at different geographical and administrative scales. Indeed, although at this stage the official consultation process had finished, an unofficial but very intense lobbying period had just begun (Richardson, 1997), targeting all three bodies, EC, EP and CM, from all directions. Between the summer of 1998 and May 1999 (when the AT came into force) unprecedented conciliation talks took place between the EP and the CM on the WFD in order to accelerate the decision-making process. However the talks were not a great success. A compromise was reached in only three out of 14 points of disagreement, namely: the inclusion of wetlands in the directive's scope; the introduction of rules for public consultation and marine conservation; and the inclusion of endocrine disrupting chemicals in the list of hazardous substances. Predictably enough, these were the least controversial points while the main points of disagreement remained unresolved. In February 1999 (2 months before the AT came into force), the EP started elaborating on its own amendments to the Commission's proposal. The EP came up with 200 amendments (most of which were linguistic clarifications) of which 133 were accepted by the Commission. The most important suggestions were to:

- incorporate the Esbjerg declaration (Rejected by the Commission);

- identify PHS for immediate cessation (Accepted);

- continuous reduction of all other hazardous substances (Accepted);

- characterize water as Europe's heritage, and not a commercial product (Rejected);

- oblige member states to report on the implementation progress (Accepted).

It should be noted that, as with the Council's position, which was an amalgamation of the positions of different member states and national lobbies, the Parliament's position was by no means a unanimously developed concurrence. Rather, it was an amalgamated majority consensus. For example, although the Parliament's agreed position was in favour of full cost 
pricing, the socialist MEPs of the south of Europe sided with the GM against full cost pricing, and characterized this clause as 'fundamentally neoliberal' because of the 'market economy' orientation of the argument and because of the economic burden it would place on farmers of the European south and on consumers of water (i.e. all citizens) throughout Europe.

When the text, amended by the EP and accepted by the EC, went back to the Council for a second reading, it was faced with strong disagreement. After its second reading, in March 1999, the Council amended the Parliament's positions by:

- rephrasing what used to be 'member states are obliged' to achieve good water status into 'member states should make an effort';

- deleting the requirement for full cost pricing;

- increasing the implementation period (34 years);

- abandoning the zero emission approach for PHS;

- increasing the list of exemptions from legally binding objectives.

With the new Council's amendments, the WFD came very close to becoming an 'empty word', with very few legally binding objectives incorporated into its main text (European Commission, 1999, $\operatorname{COM}(99) 271$; Interviews with members of the EEB, WWF and the Commission, October 2000; European Parliament, 1999; European Environmental Bureau (EEB), Press Release, 12 March 1999). There was now a clear risk that the whole project for creating a new Water Directive for Europe would be abandoned altogether unless the EP and the CM could reach an agreement and come up with a commonly acceptable text. The EP went ahead with their second reading in February 2000 in which they voted for:

- the full incorporation of the OSPAR Treaty into the WFD, which meant that all discharges of hazardous substances should stop by 2020;

- a 10 year implementation period;

- an increased number of legally binding requirements.

Given the differences between the EP's and the CM's positions, a second round of conciliatory talks became inevitable. At this stage, according to European Union procedures, the two bodies had to reach an agreement within a deadline of 6 weeks or else the project would have to be dropped altogether. During this period, heavily charged talks took place between the EP and the CM, while the Commission, as well as environmental NGOs (notably the EEB and the WWF) (Biliouri, 1999) organized meetings and discussions in an attempt to reach a political agreement without too many compromises on environmental protection.

\section{Surprise or Compromise? The Common Text for the Water Framework Directive}

On 28 June 28 2000, after an exhausting conciliatory meeting between the EP and the CM, which took place behind closed doors and went well into the early morning hours, an agreement on a common text was reached against all odds (European Commission, 2000c, Directive 2000/60/EC). In order to produce the joint text, both sides made significant compromises and, although access to the minutes of the meeting is not allowed, we can read the compromising character of the talks in the adopted common text, which has now become the WFD. The final text's compromises on the main points of controversy are:

- member states should 'aim' to achieve good water status;

- the implementation deadline was set at 15 years;

- the controversial groundwater protection article was dropped and the requirement for a 
'daughter directive' on groundwater protection was incorporated into the main text as an obligation;

- PHS should be eliminated in 20 years after the publication of a list defining PHS (European Parliament, 2000, 2001a);

- full cost recovery should be 'taken into account' (European Parliament, 2001b);

- member states can opt out of environmental cost recovery;

- water was defined as Europe's heritage and not as a commercial product.

In September 2000, the directive's common text came into the Plenary Session of the EP where it received final approval. The WFD came into force in 22 December 2000. From that date onwards, member states were given 3 years (until December 2003) to transpose the WFD into national legislation, facing strict financial implications should they fail to comply with the requirement. However, being the product of a compromise, the final text is more of a tool rather than a strict piece of legislation per se (Kallis \& Butler, 2001; Lanz \& Scheuer, 2001). Most of the controversial passages have been hedged in such a way that member states can interpret them in different ways. This makes the implementation phase immensely important, and gives particular executive powers to the actors who will participate in this phase.

\section{Turning Text into Praxis: Manufacturing Social Capital and Resurrecting the State}

As we have seen, producing the final joint text for the WFD proved a difficult and conflicting task, but is by no means the end of the story. Given its 'framework' character, the directive has to be 'translated' to national and regional/local (river basin) context. Its 'materialization' involves a significant modification of the existing social capital (Durston, 1999; Diani, 2000; Paraskevopoulos, 2001) involved in water management at the national and local levels, including the establishment and operation of new agencies and institutions, and incurring considerable costs. Thus, it can be argued that changes in social capital are essential in order to create the conditions that will facilitate the achievement of the Directive's goals.

In fact, the WFD, with its mandate for new institutions, agencies and decision-making procedures, can be seen as a top-down effort to create social capital (see Figure 2), which will inevitably interact with existing social capital at the national and local levels. However, as we have seen, local authorities around Europe have already expressed serious considerations about handing power over to the river basin authorities. Similarly, regulatory bodies and institutions will have to face a restructuring of their duties and, in many cases of the geographical territory in which they currently operate. Research has shown that the successful implementation of past European Union water directives (such as the drinking and the bathing water directives) was associated with the successful establishment of processes and institutions (e.g. monitoring schemes, public announcement of compliance with standards, etc.) that raised public awareness and interest, and encouraging achievement of standards (Hassan, 1995; Ward et al., 1997). In a similar manner, it could be argued that the interaction of the institutions, actors and norms created by the WFD with the existing ones at the local level will determine, to a great extent, the successful implementation of the Directive.

However, the top-down process of changing the social capital basis through the WFD should not be overestimated (Buckland, 1998; Schuller et al., 2001). As we have seen, the WFD is not the only factor that is changing water policy in Europe. The increasing involvement of the private sector in water management adds an extra complication, while at the national level the role of the state remains instrumental, thus making the formation of social capital a three-part process between the State, civil society and the private sector (the market) (Figure 3), 


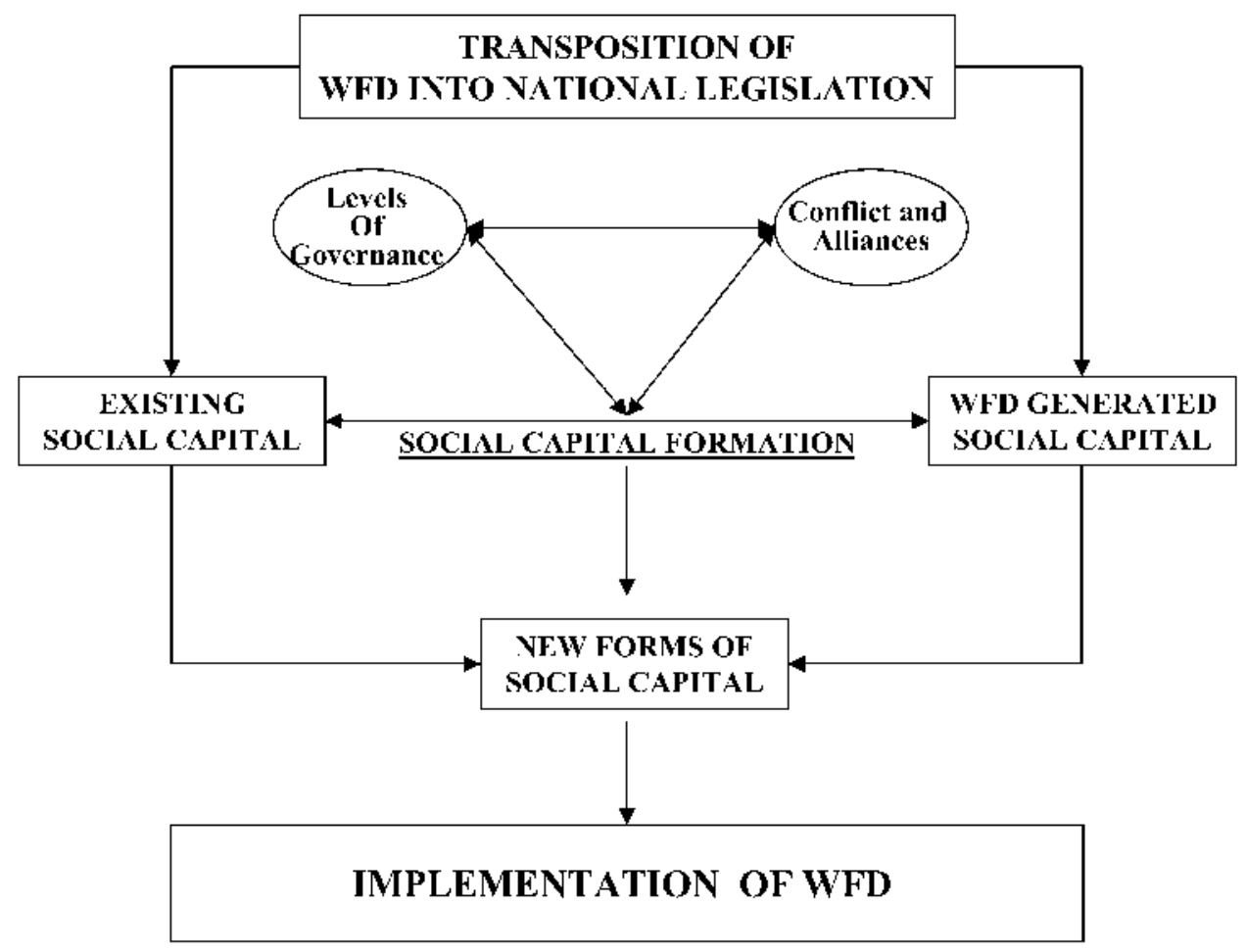

Figure 2. WFD as a top-down effort to create social capital.

and the relationship between regulation, liberalization and environmental protection an increasingly complex and important one (Cox \& Jonas, 1993; Clark \& Root, 1999; Moulaert, 2000; Le Galès, 2002).

However, regardless of the particular national responses to the earlier relationship and regardless of the national, regional and local configurations that social capital formation may

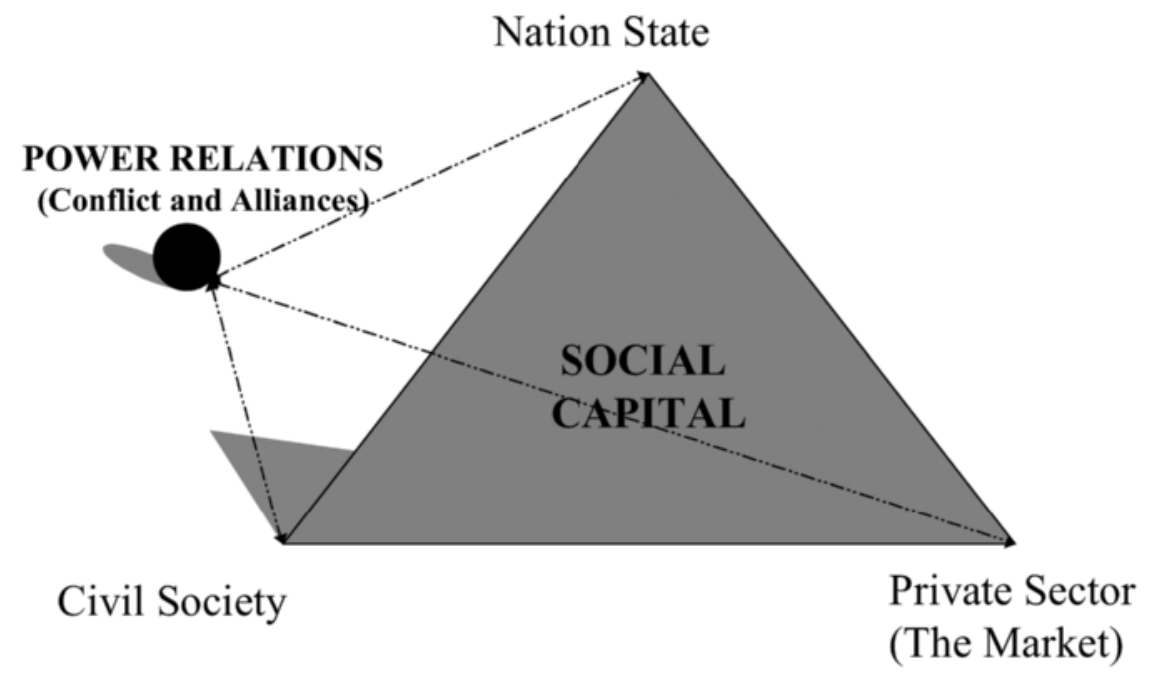

Figure 3. The three way process of change. 
take, it should be noted that, unless social issues are addressed alongside environmental issues, Europe could be faced with what the industry promotes as the 'inevitable social costs' of environmental protection. These range from higher prices for water, food and chemical products (Hackitt, 2000; Bolt, 2000), to the promotion of redundancy policies to compensate for an increase in operational costs that is supposedly due to practices of environmental protection (Littlechild, 1988; Maloney, 1994).

In conclusion, water supply management and protection remains as thorny an issue as ever, but the social aspects of environmental protection cannot be left to the promotion of social capital formation alone, or to the hand of the market to resolve. Given that social capital cannot be created instantly and given the ample evidence in the literature that the very fact of trying to create it top-down or directly can create resistance and lead to a failure of the very policies it intends to foster (Roseland, 2000), the quality of the interface between the Directive as a top-down effort to create social capital and the existing social capital at the member state level, conditioned by the dominant trend of liberalization, will determine to what extent the challenge of producing a better environment for Europe will match the demand for making Europe's society more egalitarian.

\section{Acknowledgements}

The research for this paper was carried out under the first phase of the EU funded (Framework V) project: "Achieving Sustainable and Innovative Policies through participatory governance in a multi-level context". Many thanks to Dr Erik Swyngedouw for the valuable comments and inspiration. Thanks also to Dr Ben Page, who collaborated on this project, for his important comments and input and to Alex Loftus for his comments on earlier versions. Special thanks to: the European Commission, Environment DG; the European Environmental Bureau (EEB) (Stefan Scheuer, in particular); the Brussels office of the World Wildlife Fund (WWF) (Eva Royo Gelabert in particular); all the anonymous interviewees for their precious input.

\section{References}

ANon (1994) Free market for the land of the free?, Water and Environment International, 3, pp. 14-15.

BÄr, S. and KraEmer, A. (1998) European environmental policy after Amsterdam, Foumal of Environmental Law, 10, pp. 315-330.

BILIOURI, D. (1999) Environmental NGOs in Brussels: how powerful are their lobbying activities? Environmental Politics, 8, pp. 173-185.

BloECH, H. (1999) The European union water framework directive: taking European water policy into the next millennium?, Water, Science and Technology, 40, pp. 67-71.

Bolt, S. (2000) Water supply and disposal, Water Framework Directive Conference. The Barbican, London, 7th Nov. 2000 (ICE magazine, EA and WaterUK).

Boymanns, D. (1997) The EEBs Position on the Proposal for a Water Framework Directive. Brussels: European Environment Agency.

BUCKLAND, J. (1998) Social capital and sustainability of NGO intermediated development projects in Bangladesh, Community Development Joumal, 33, pp. 236-248.

Burkitt, B. and Ashton, F. (1996) The birth of the stakeholder society, Critical Social Policy, 16, pp. 3-16.

Clark, G.L. and Root, A. (1999) Infrastructure shortfall in the United Kingdom: the private finance initiative and government policy, Political Geography, 18, pp. 341-365.

Coleman, J. (1988) Social capital and the creation of human capital, American fournal of Sociology, 94, pp. S95-S120.

Cox, K.R. and Jonas, A.E.G. (1993) Urban development, collective consumption and the politics of metropolitan fragmentation, Political Geography, 12, pp. 8-37. 
DA-CunHA, L.V. (1989) Water resources situation and management in the EEC, Hydrogeologie, 2, pp. $57-69$.

DiAnI, M. (2000) Social capital, participation in associations, and institutional trust, Capitale sociale, partecipazione associativa e fiducia istituzionale, Rivista italiana di scienza politica, XXX, pp. 575-511.

Durston, J. (1999) Building community social capital, CEPAL review, 69, pp. 103-118.

ERnst, J. (1994) Whose Utility? The Social Impact of Public Utility Privatization and Regulation in Britain. Buckingham and Philadelphia, PA: Open University Press.

European Commission (1992) Towards Sustainability: A European Community Programme of Policy and Action in Relation to the Environment and Sustainable Development. GOM(92)23 Final Volume II. Brussels: European Commission.

European Commission (1996). Proposal for a European Parliament and Council Decision on an Action Programme for Integrated Groundwater Protection and Management. COM(96)315 Final. Brussels: European Commission.

European Commission (1997). Proposal for a Council Directive Establishing a Framework for Community Action in the Field of Water Policy. COM(97)49 Final. Brussels: European Commission.

European COMMission (1998) Guide to the Approximation of the European Union Environmental Legislation, revised from SEG(97) 1608 of 25 August 1997. Brussels: European Commission.

European Commission (1999) Proposal for a Council Directive Establishing a Framework for Community Action in the Field of Water Policy. COM(99)271, 17 June 1999. Brussels: European Commission.

European COMMission(2000a) White paper on Environmental Liability. 9 February 2000, COM 2000 (66) Final. Brussels: European Commission.

EUROPEAN COMMISSION (2000b) Handbook on the Implementation of EC Environmental Legislation. (COM (97) 49 Final, 30 October 2000. Brussels: European Commission.

European Commission (2000c) Directive 2000/60/EC of the European Parliament and of the Council of 23 October 2000 Establishing a Framework for Community Action in the Field of Water Policy. Official Journal 22 December 2000 L 327/1. Brussels: European Commission.

European Commission (2001) Common Strategy on the Implementation of the Water Framework Directive. DG Environment, Strategic Document, May 2001. Brussels: European Commission.

European Commission Environment Water TAsk Force (ECEWTF) (1997) Working document presented at the validation workshop on water research priorities for Europe, Baveno, Italy.

European Environment AgEncy (EEA) (1995) Europe's Environment - The Dobris Assessment, D. STANners and P. Bourdeau (Eds). Copenhagen: European Environment Agency.

European Environment Agency (EEA) (1998) Europe's Environment: The Second Assessment. Copenhagen: European Environment Agency.

European Environment AgEncy (EEA) (1999a) Groundwater Quality and Quantity in Europe. Environmental assessment report no. 3. Copenhagen: European Environment Agency.

European Environment AgEncy (EEA) (1999b) Environment in the European Union at the Turn of the Century, Chapt. 3.5. Copenhagen: European Environment Agency.

European Environment Agency (EEA) (1999c) Sustainable Water Use in Europe-Sectoral Use of Water. Environmental assessment report no. 1. Copenhagen: European Environment Agency.

European Environment Agency (EEA)/European Topic Gentre on Inland Waters (ETC/IW) (1996) Water Resources Problems in Southern Europe. Topic report no. 15, 45 pp. Copenhagen: European Environment Agency.

European Parliament (1999) Draft Recommendation for Second Reading on the Common Position Adopted by the Council with a View to the Adoption of a European Parliament and Council Directive on Establishing a Framework for Community Action in the Field of Water Policy. PE 231.246, 26 November 1999, http:// www.europarl.eu.int/meetdocs/committees/envi/20000125/381796_en.doc.

European Parliament (2000) Draft Report on the Proposal for a European Parliament and Council Decision Establishing the List of Priority Substances in the Field of Water Policy, PE 293.659, 8th August, 2000, http://www.europarl.eu.int/meetdocs/committees/envi/20001009/414353_en.doc.

European Parliament (2001a) Legislative Resolution on the Amended Proposal for a European Parliament and Council Decision Establishing the List of Priority Substances in the Field of Water Policy. (COM(2000) 47- $\mathrm{COM}(2001))$. 
European Parliament (2001b) Draft Report on the Commission Communication to the Council, the European Parliament and the Economic and Social Committee on Pricing Policies for Enhancing the Sustainability of Water Resources, PE 304.663, 31 May 2001, http://www.europarl.eu.int/meetdocs/committees/envi/ 20010618/438985en.pdf.

European Topic Gentre On InLand Waters (ETC/IW) (1998) Groundwater Quality and Quantity in Europe. COM(96) 500, 22 October 1996 (report by A. Scheidleder, J. Grath, G. Winkler, U. StÄrk, C. Koreimann and C. Gmeiner, Austrian Working Group on Water). EEA Monograph PO26/ $97 / 1$.

Faure, G. and Rubin, J.Z. (1993) Culture and Negotiation: The Resolution of Water Disputes. London: Sage, Newbury Park. Sponsored jointly by the United Nations Educational, Scientific, and Cultural Organization and the International Institute for Applied Systems Analysis.

Frederiksen, H. (1930) and World Bank (1992) Water Resources Institutions: Some Principles and Practices. Washington, DG: World Bank.

Garrod, G. and Willis, K.G. (1994) The Transferability of Environmental Benefits: A Review of Recent Research in Water Resources Management. Newcastle upon Tyne: Gentre for Rural Economy, Department of Agricultural Economics and Food Marketing, University of Newcastle upon Tyne.

GiLberT, G.K.C.C. (2000) Integrating the Directive with the Statutory Planning Framework, in Water Framework Directive Conference, The Barbican, London, 7 November 2000: ice magazine, EA and Water UK.

Gleick, P.H. (1993) Water in Crisis: A Guide to the World's Fresh Water Resources. New York and Oxford: Oxford University Press.

Gottlieb, R. (1988) A Life of its Own: The Politics and Power of Water. San Diego, CA and London: Harcourt Brace Jovanovich.

Goubert, J.P. (1989) The Conquest of Water. Cambridge: Polity Press.

HACkitT, J.C.I.A. (2000) Hazardous Substances, in Water Framework Directive Conference, The Barbican, London, 7 November 2000: ice magazine, EA and Water UK.

Harrison, A., Schmidt, G., Avis, C. and Hauser, R. (2001) WWF's Preliminary Comments on Public Participation in the Context of the Water Framework Directive and Integrated River Basin Management. Copenhagen: WWF European Freshwater Programme.

HARvey, D. (1989) From managerialism to entrepreneurialism: the transformation in urban governance in late capitalism, Geografiska annaler, 71, pp. 3-17.

Hassan, J. (1995) The impact of EU environmental policy on water industry reform, European Environment, 5, pp. $45-51$.

Henton, P.S. (2000) Implementing the Directive: the View of the Regulator, in Water Framework Directive Conference, The Barbican, London, 7 November 2000: ice magazine, EA and Water UK.

Hundley, N. (1992) The Great Thirst. Berkeley and Los Angeles, CA: University of California Press.

International Gentre of Water Studies (ICWS) (1996) Long-range Study on Water Supply and Demand in Europe Integrated Report. Report 96.05 to the EC-Forward Studies Unit. Amsterdam: ICWS.

Jessop, B. (1997) Capitalism and its future: remarks on regulation, government and governance, Review of International Political Economy, 4, pp. 561-582.

Kallis, G. and Butler, D. (2001) The EU water framework directive: measures and implications, Water Policy, 3, pp. 125-142.

Kallis, G. and NiJKamp, P. (2000) Evolution of EU water policy: a critical assessment and a hopeful perspective, Foumal of Environmental Law and Policy, 3, pp. 301-355.

KEARns, A. (1995) Active citizenship and local governance- political and geographical dimensions, Political Geography, 14, pp. 155-175.

Lanz, K. and Scheuer, S. (2001) EEB Handbook on EU Water Policy under the Water Framework Directive. Brussels: EEB.

LE Gales, P. (2002) European Cities: Social Conflicts and Governance. Oxford: OUP.

LiTTLECHILD, S. (1988) Economic regulation of privatised water authorities and some further reflections, Oxford Review of Economic Policy, 4, p. 2.

Maloney, W.A. (1994) Privatisation and employment relations - the case of the water industryDavidson, Jd., Public Administration, 72, pp. 615-615.

Meyer, U. (1988) The EU water framework directive: the importance of incorporating Esbjerg Declaration, Oceanographic Literature Review, 45, pp. 1428-1428.

Moulaert, F. (2000) Globalization and Integrated Area Development in European Cities. Oxford: OUP. 


\section{Maria Kaika}

Neto, F. (1998) Water privatization and regulation in England and France: a tale of two models, Natural Resources Forum, 22, pp. 107-117.

OgDen, S.G. (1995) Transforming frameworks of accountability - the case of water privatization, Accounting Organizations and Society, 20, pp. 193-218.

Paraskevopoulos, G.J. (2001) Social capital, learning and EU regional policy networks: evidence from Greece, Government and Opposition, 36, pp. 253-278.

Postel, S. (1992) The Last Oasis: Facing Water Scarcity. London: Earthscan.

Pretty, J. and Hine, R. (1999) Participatory Appraisal for Community Assessment: Principles and Methods. Colchester: Centre for Environment and Society, University of Essex.

Pretty, J. and Ward, H. (2001) Social capital and the environment, World Development, 29, pp. $209-227$. PutNAM, R.D. (1995) Bowling alone: America's declining social capital, Jounal of Democracy, 6, pp. 65-78.

Reisner, M. (1990) Cadillac Desert: The American West and its Disappearing Water. London: Secker \& Warburg.

RICHARDSON, J. (1997) EU water policy: uncertain agendas, shifting networks and complex coalitions, Environmental Politics, 3, pp. 139-167.

Roseland, M. (2000) Sustainable community development: integrating environmental, economic, and social objectives, Progress in Planning, 54, pp. 73-132.

SALETH, R.M. (2000) Institutional changes in global water sector: trends, patterns, and implications, Water Policy, 2, pp. 175-199.

Schuller, T. and Baron, S.R. (2001) Social Capital: Critical Perspectives. Oxford: Oxford University Press.

Swyngedouw, E. (1997) Power, nature, and the city: the conquest of water and the political ecology of urbanization in Guayaquil, Ecuador: 1880-1990, Environment and Planning A, 29, pp. 311-332.

Swyngedouw, E. (2000) Authoritarian governance, power and the politics of rescaling, Environment and Planning D: Society and Space, 18, pp. 63-76.

Swyngedouw, E., Kaika, M. and Castro, E. (2000) Urban water: a political-ecology perspective, Built Environment, 28(2), pp. 124-137.

Tompkins, J. (2000) Diffuse Pollution, in Water Framework Directive Conference, The Barbican, London, 7 November 2000: ice magazine, EA and Water UK.

Ward, N., Lowe, P. and Buller, H. (1997) Implementing European water quality directives: lessons for sustainable development, in S. BAKer, M. Kousis, D. Richardson and S. Young (Eds) The Politics of Sustainable Development, Global Environmental Change Series. London: Routledge.

WATER UK (2001) Water Framework Directive: Response to UK Government Consultation, 17 July 2001.

Wood, A. (2001) Preparing the Agency for the Implementation of the Water Framework Directive. Environment Agency UK.

WoOlcock, M. (1998) Social capital and economic development: toward a theoretical synthesis and policy framework, Theory and Society, 27, pp. 151-208.

WORLd Wildlife Fund (WWF) (2000) EU Water Framework Directive: A History of Negotiations and Lobbying 1999-2000, last update on 13 November 2000. WWF living waters programme, www.panda.org. 